\title{
Limited durability of expandable pericardial tissue valves in the mitral position in children
}

Eric R. Griffiths, MD, ${ }^{\mathrm{a}, \mathrm{b}}$ Robert G. Gray, MD, ${ }^{\mathrm{b}, \mathrm{c}}$ Mary Hunt Martin, MD, ${ }^{\mathrm{b}, \mathrm{c}}$ S. Adil Husain, MD, ${ }^{\mathrm{a}, \mathrm{b}}$ and Aaron W. Eckhauser, MD, a,b Salt Lake City, Utah

From the a Section of Pediatric Cardiothoracic Surgery, Division of Cardiothoracic Surgery, Department of Surgery, and ${ }^{\mathrm{c}}$ Division of Cardiology, Department of Pediatrics, University of Utah, Salt Lake City, Utah; and ${ }^{\mathrm{b}}$ Primary Children's Hospital, Intermountain Healthcare, Salt Lake City, Utah.

Disclosures: The authors reported no conflicts of interest.

The Journal policy requires editors and reviewers to disclose conflicts of interest and to decline handling or reviewing manuscripts for which they may have a conflict of interest. The editors and reviewers of this article have no conflicts of interest.

Accepted for the 100th Annual Meeting of The American Association for Thoracic Surgery.

Received for publication Oct 15, 2020; accepted for publication Oct 15, 2020; available ahead of print Oct 24, 2020.

Address for reprints: Eric R. Griffiths, MD, Section of Pediatric Cardiothoracic Surgery, Primary Children's Hospital, 100 N Mario Capecchi Dr, Salt Lake City, UT 84123 (E-mail: Eric.griffiths@hsc.utah.edu).

JTCVS Techniques 2021;5:84-6

2666-2507

Copyright $(2020$ The Authors. Published by Elsevier Inc. on behalf of The American Association for Thoracic Surgery. This is an open access article under the CC BY-NC-ND license (http://creativecommons.org/licenses/bync-nd/4.0/).

https://doi.org/10.1016/j.xjtc.2020.10.014

Balloon-expandable tissue valves are attractive options for small children requiring mitral valve replacement. ${ }^{1,2}$ The Sapien 3 valve (Edwards, Irvine, Calif) is a transcatheter balloon-expandable valve constructed from bovine pericardium. We report our experience with 5 patients who underwent surgical implantation of this valve, with subsequent explantation or percutaneous valve-in-valve reintervention in all 5 patients. This was an off-label use of these valves which are designed for transcatheter placement in the aortic position in adults.

The Institutional Review Board approved this study (00116237; April 5, 2019) and waived the need for informed consent.

\section{CASE DESCRIPTION}

The surgical implantation technique was similar across all 5 implantations. Excessive valve and subvalvular tissue was excised, and the annulus size was determined. Either a $20-\mathrm{mm}$ or $23-\mathrm{mm}$ valve was crimped over an $8-\mathrm{mm}$ dilator. A 4-0 monofilament purse string suture was placed circumferentially around the annulus. A second purse string suture of 4-0 monofilament secured the valve skirt to the annulus circumferentially. The valve was balloonexpanded under direct vision, and the 2 suture lines were tied down. Patch augmentation of the atrial septum was frequently required.

The first 2 implanted patients were treated with clopidogrel for 3 months and with low-dose aspirin indefinitely. The subsequent 3 patients were treated with warfarin for 3 months and with low-dose aspirin indefinitely.

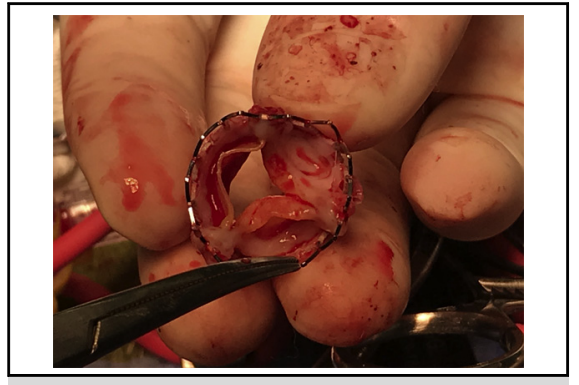

Early failure of 5 surgically implanted balloonexpandable pericardial tissue valves.

CENTRAL MESSAGE

Five surgically implanted balloonexpandable pericardial tissue valves in the mitral position performed poorly in children. Oversizing and underexpansion were likely the sources of failure.

See Commentary on page 87.

A total of 5 valves were implanted over a period of 3 years: three $20-\mathrm{mm}$ valves and two $23-\mathrm{mm}$ valves. The age range of patients at first implantation was 6 months to 14 years. Two patients had previously repaired complete atrioventricular canal defects, and 2 patients had Shone's syndrome. One patient had a partial atrioventricular canal defect (see Table 1).

All 5 patients experienced failure of the valve necessitating either surgical replacement or percutaneous valve-in-valve replacement. There were 5 catheter-based reinterventions in 3 patients -3 balloon dilations and 2 valve-in-valve replacements (a $26-\mathrm{mm}$ valve within a $23-\mathrm{mm}$ valve and a $20-\mathrm{mm}$ valve within a $23-\mathrm{mm}$ valve). The median time to valve replacement following initial implantation was 14 months (range, 3-27.8 months).

There were 2 trivial to mild paravalvular leaks and 1 moderate to severe paravalvular leak, all of which resolved with subsequent balloon dilation. One patient had a left ventricular outflow tract obstruction that contributed to valve removal. Other complications of implantation were left lower pulmonary vein stenosis and pacemaker placement. 
There was 1 death from a neurologic injury after a percutaneous valve-in-valve replacement.

\section{DISCUSSION}

Although the balloon-expandable pericardial tissue valve appeared to be promising due to the shorter profile, more durable stent, and sealing skirt facilitating surgical implantation, we report limited durability and freedom from reintervention.

Leaflet dysfunction was the mode of failure for the majority of explanted valves. Three valves (all $20 \mathrm{~mm}$ ) had significant tissue ingrowth onto the valve leaflets inhibiting proper valve function (see Figure 1). The immobile leaflets and pannus were present in all of the smaller patients (weight $5-14 \mathrm{~kg}$ ). The 26-mm valve implanted percutaneously within the 23-mm Sapien XT showed good leaflet mobility without any tissue ingrowth; however, the diameter of the valve at time of surgical explantation was $<16 \mathrm{~mm}$, thereby leading to mitral stenosis.

The valves were underexpanded in 4 out of 5 patients at the time of implantation, with the idea that further expansion could occur with patient growth. Even with underexpansion, the implanted valves were all oversized relative to patient size. This resulted in a significantly enlarged mitral annulus relative to patient size. In addition, underexpansion of the valve could have limited proper leaflet function. Unlike the thin, natural bovine jugular vein leaflets within the Melody valve, the Sapien valve leaflets are constructed of treated bovine pericardium. ${ }^{3,4}$ These leaflets are thicker and potentially less compliant, possibly limiting the mobility of the leaflets in smaller patients with less blood flow across the valve. The impaired leaflet movement could

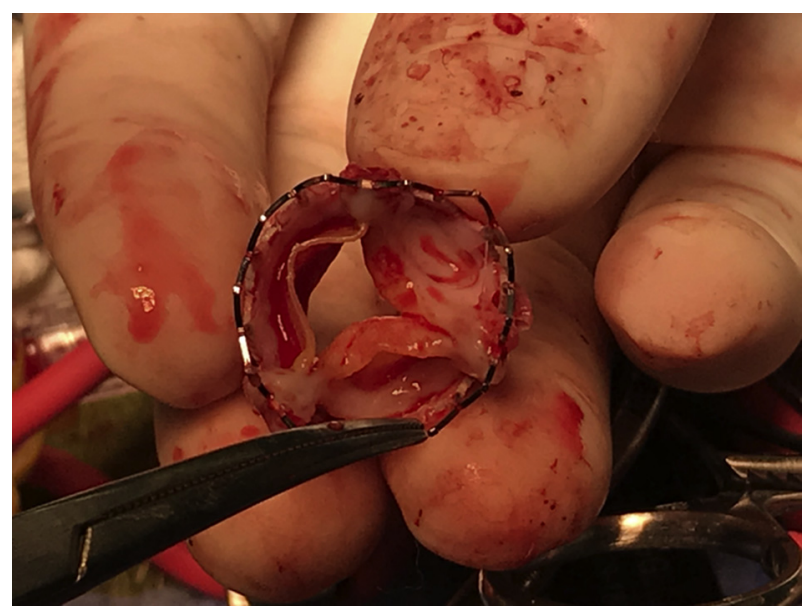

FIGURE 1. A Sapien 3 20-mm balloon-expandable pericardial tissue valve was explanted from the mitral position in a 10 -month-old child due to severe regurgitation at 7 months after surgical implantation. Significant pannus formation impaired leaflet mobility.

lead to early pannus formation and stenosis. The accelerated calcification of pericardial tissue valves that seems to be more pronounced in children than adults also could have played a role in the early failure of the leaflets.

What role anticoagulation strategy played in the early failure of these valves is unclear. The last implanted patient had full expansion of the valve and early anticoagulation with heparin and warfarin but still developed early valve failure with impaired leaflet mobility.

In our limited series, the surgically implanted balloon expandable pericardial tissue valve performed poorly in the young pediatric population. Oversizing of the valve relative

\section{TABLE 1. Patient information}

\begin{tabular}{|c|c|c|c|c|c|c|c|}
\hline Diagnosis & $\begin{array}{c}\text { Age/weight at } \\
\text { implantation }\end{array}$ & $\begin{array}{l}\text { Valve } \\
\text { size }\end{array}$ & $\begin{array}{c}\text { Fully } \\
\text { expanded }\end{array}$ & $\begin{array}{c}\text { Time to } \\
\text { replacement }\end{array}$ & $\begin{array}{c}\text { Mode of } \\
\text { pericardial } \\
\text { valve failure }\end{array}$ & Complications & Comments \\
\hline $\begin{array}{l}\text { Shone's } \\
\text { syndrome }\end{array}$ & $14 \mathrm{y} / 64 \mathrm{~kg}$ & $23 \mathrm{~mm}$ & No $(18$ mm) & $\begin{array}{l}\text { Valve-in-valve } \\
\text { at } 14 \mathrm{mo} \text {; MVR } \\
\text { mechanical } \\
\text { at } 27 \mathrm{mo}\end{array}$ & $\begin{array}{l}\text { Stenosis and } \\
\text { regurgitation; } \\
\text { stenosis }\end{array}$ & $\begin{array}{r}\text { Balloon dilation for } \\
\text { paravalvular leak }\end{array}$ & $\begin{array}{l}\text { Valve leaflets pliable at } \\
\text { explant but } \\
\text { underexpanded cage }\end{array}$ \\
\hline CAVC & $2.5 \mathrm{y} / 14.3 \mathrm{~kg}$ & $20 \mathrm{~mm}$ & No $(18 \mathrm{~mm})$ & $\begin{array}{r}14 \text { mo; MVR } \\
\text { mechanical }\end{array}$ & $\begin{array}{l}\text { Stenosis and } \\
\text { regurgitation }\end{array}$ & $\begin{array}{l}\text { Balloon dilation for } \\
\text { paravalvular leak; left } \\
\text { lower pulmonary vein } \\
\text { stenosis; PHTN }\end{array}$ & $\begin{array}{l}\text { Explanted valve with } \\
\text { pannus on leaflets }\end{array}$ \\
\hline $\begin{array}{l}\text { Shone's } \\
\text { syndrome }\end{array}$ & $4.8 \mathrm{y} / 19.8 \mathrm{~kg}$ & $23 \mathrm{~mm}$ & No $(18 \mathrm{~mm})$ & $\begin{array}{l}26 \mathrm{mo} ; \\
\quad \text { valve-in-valve, } \\
20 \mathrm{~mm}\end{array}$ & Stenosis & $\begin{array}{l}\text { Balloon dilation for } \\
\text { paravalvular leak after } \\
\text { initial implant }\end{array}$ & $\begin{array}{l}\text { Postprocedural } \\
\text { hemorrhagic stroke } \\
\text { leading to death }\end{array}$ \\
\hline CAVC & $10 \mathrm{mo} / 7.6 \mathrm{~kg}$ & $20 \mathrm{~mm}$ & Yes $(20 \mathrm{~mm})$ & $\begin{array}{l}7 \text { mo; MVR } \\
\text { mechanical }\end{array}$ & Regurgitation & $\begin{array}{l}\text { Delayed-onset heart block } \\
\text { requiring pacemaker }\end{array}$ & $\begin{array}{l}\text { Explanted valve with } \\
\text { pannus on leaflets }\end{array}$ \\
\hline $\begin{array}{l}\text { Partial } \\
\text { AVC }\end{array}$ & $5 \mathrm{mo} / 5.6 \mathrm{~kg}$ & $20 \mathrm{~mm}$ & No $(18 \mathrm{~mm})$ & $\begin{array}{l}3 \text { mo; valve } \\
\text { excision, VAD } \\
\text { placement }\end{array}$ & Stenosis & $\begin{array}{l}\text { LVOTO (Konno } \\
\text { procedure); decreased } \\
\text { left ventricular function }\end{array}$ & $\begin{array}{c}\text { Explanted valve with } \\
\text { pannus on leaflets }\end{array}$ \\
\hline
\end{tabular}

$M V R$, Mitral valve replacement; $C A V C$, complete atrioventricular canal; $P H T N$, pulmonary hypertension; $A V C$, atrioventricular canal; $V A D$, ventricular assist device; $L V O T O$, left ventricular outflow tract obstruction. 
to patient size and under-expansion of the leaflets were likely the sources of failure. Perhaps larger patients where the valve can be fully expanded might experience a better outcome. However, caution should be used when surgically implanting the valve in small children and adolescents as we experienced a short time to failure, even in the presence of anticoagulation.

\section{References}

1. Trezzi M, Cetrano E, Iacobelli R, Carotti A. Edwards Sapien 3 valve for mitral replacement in a child after Melody valve endocarditis. Ann Thorac Surg. 2017; 104:e429-30.
2. Chai PJ, George I, Nazif TM, Kalfa DM, Kodali SK, Torres AJ, et al. Use of stented bovine pericardial valve for surgical mitral valve replacement in infants. J Thorac Cardiovasc Surg. 2016;151:e51-2.

3. Quinonez LG, Breitbart R, Tworetsky W, Lock JE, Marshall AC, Emani SM. Stented bovine jugular vein graft (Melody valve) for surgical mitral valve replacement in infants and children. J Thorac Cardiovasc Surg. 2014;148: 1443-9.

4. Pluchinotta FR, Piekarski BL, Milani V, Kretschmar O, Burch PT, Hakami L, et al Surgical atrioventricular valve replacement with Melody valve in infants and children. Circ Cardiovasc Interv. 2018;11:e007145.

5. Cheung A, Webb JG, Barbanti M, Freeman M, Binder RK, Thompson C, et al. 5-year experience with transcatheter transapical mitral valve-in-valve implantation for bioprosthetic valve dysfunction. J Am Coll Cardiol. 2013; 61:1759-66. 